\title{
INFORUM 2008
}

The 14th Annual Conference of INFORUM was held in Prague from 28 to 30 May 2008. The conference was organised by Albertina icome Praha s.r.o., a distributor of electronic information resources in the Czech and Slovak Republic, and the University of Economics, Prague.

This conference dealt with professional electronic information resources for research, development, education and business purposes. The conference had more international representatives attending this year. The original territorial focus on the Czech Republic and Slovakia has been expanded to the other Central and Eastern European countries since 2003 and it has become the main event in this field in the region. The conference was attended by information professionals from special and public libraries, private corporations and state agencies, IT managers, physicians, lawyers, university teachers and students.

There were half-day workshops on subjects such as "Changing requirements for teaching and learning for professional education", "Sharing bibliographic data: Chance or a risk for libraries in the Web 2.0?", and of course my own workshop, "Marketing of electronic resources". It is always good to know something about "Trends and updates in the field of electronic information resources" and about "Electronic information resources in e-learning and e-learning". For corporate libraries there was an opportunity in session to discuss "Sharing and flowing of information in the business sector" and, as always, a session about "Searching the Web and heterogeneous information resources for institutions", which also contained interesting and new information. The session about "Evaluation of results of scientific research with the help of electronic information resources" was very well received and presented new aspects of evaluation. "Digital libraries - trends, technologies, solutions" and "Operational aspects of using electronic information resources" were also successful sessions.

I also want to mention the important INFOPARTY, organised in co-operation with the National Library of the Czech Republic with an INFOCONCERT in the wine yard at the old building Klemetinum (Czech National Library). Here the Inforum 2008 Awards were awarded to the most important Czech and Slovak products, services or acts related to electronic information.

The INFORUM exhibition brings together information and software providers, as well as aggregators, publishers and subscription agents. 